\title{
Inquiry-Based Learning in the Natural Sciences
}

\author{
Andrea Ruf, Ingrid Ahrenholtz, and Sabine Matthé
}

\subsection{Characteristic Features in the Natural Sciences in Terms of Inquiry-Based Learning}

Instruction in the natural sciences of biology, chemistry, the marine sciences and physics is inconceivable without reference to research. Students are trained to take up the profession of "scientist" and faculty often recruit or recommend doctoral students from among former students in their own courses. This practice includes a high proportion of course elements in which students themselves become active such as internships, tutorials and excursions, which usually already correspond precisely with the method of working or at least the methods being used in current research (see Box 18.1 for an example in genomics research).

Interdisciplinary and project-like courses dealing with concrete, socially relevant topics were established due to reform initiatives at universities in the 1970s and the environmental protection and conservation movements in the 1980s (Fichten et al. 1978; Wildt 1981; Jung 1997). In the area of the natural sciences, for example, students have dealt with forest dieback, pollution from chemicals or the effect of radioactivity on the environment.

A. Ruf, PD Dr. $(\bowtie)$

Fakultät für Natur- und Sozialwissenschaften, Universität Vechta, Vechta, Germany

e-mail: andrea.ruf@uni-vechta.de

I. Ahrenholtz, Dr. · S. Matthé

Carl von Ossietzky Universität Oldenburg, Fakultät für Mathematik und Naturwissenschaften,

Oldenburg, Germany

e-mail: ingrid.ahrenholtz@uni-oldenburg.de; s.matthe@uni-oldenburg.de

H. A. Mieg (ed.), Inquiry-Based Learning - Undergraduate Research,

https://doi.org/10.1007/978-3-030-14223-0_18 


\section{Box 18.1: Tapping the Potential of Undergraduate Researchers - The Genomics Education} Partnership (GEP). Reprinted from Genetics Society of America (2015) with permission Recent reports on undergraduate education have emphasized the crucial role of authentic research experiences. A genomics research article published in the May issue of G3: Genes|Genomes|Genetics allowed 940 undergraduate students not only to engage in original scholarship, but also to be authors on a peer-reviewed scientific paper. The research, on the evolution of an unusual chromosome in fruit flies, was powered by the contributions of students at 63 higher education institutions across the US, coordinated by the Genomics Education Partnership (GEP).

"By organizing the efforts of 'massively parallel' undergrads, we can solve problems that would defeat other methods," says GEP program director Sarah Elgin of Washington University in St. Louis. "At the same time, students learn how to handle the messiness of real data, to evaluate different kinds of evidence, and to justify their conclusions."

The GEP is a collaboration between faculty at a growing number of institutions and the Biology Department and The Genome Institute at Washington University in St. Louis. The GEP's goals are to introduce bioinformatics into the undergraduate curriculum and to integrate research experience into the academic year. With this classroom-based approach, many more students can access educational opportunities normally restricted to those who secure one of the small number of summer research spots available to undergraduates.

The GEP faculty and staff oversaw the project and drafted the paper, but each of the 940 students listed as a co-authors performed original research and read and approved the manuscript before submission. Many students also provided important comments that were incorporated into the final version.

The GEP students tackled the investigation of the "dot" chromosome of Drosophila fruit flies. The dot chromosome gets its name from its tiny size; next to the other fruit fly chromosomes, it looks like a compact dot.

Scientists are interested in the dot chromosome because its DNA is tightly packaged in a form called heterochromatin - a state normally linked with relatively inactive genome regions that contain only a few rarely expressed genes. But despite being packed into heterochromatin, a large region of the dot chromosome carries a similar density of actively expressed genes compared to other, non-heterochromatic parts of the fruit fly genome. Non-heterochromatic DNA is known as euchromatin.

How has this unusual state affected evolution of the dot chromosome genes? To investigate, the GEP team wanted to compare the dot chromosome to a euchromatic region from a different chromosome. But this exploration required a high quality genome sequence from several different Drosophila species, not just Drosophila melanogaster, the species in which the dot chromosome has been most intensively studied. 


\section{Box 18.1: (continued)}

Draft genome sequences for other Drosophila species were already publicly available, but because the dot chromosome carries many repetitive sequences, the genome data was sometimes unreliable. That's because repeat sequences cause trouble for the software that stitches together the fragments of raw sequence data - like a jigsaw puzzle with many pieces of the same color and shape, it's hard to figure out which fragments belong where.

In this case, humans do a better job than computers. The GEP was able to correct errors in the draft genome assembly by breaking the work up into chunks and distributing it among hundreds of students. The students carefully examined each region they were assigned and paid attention to small differences in repeated sequences that gave them clues on how to put the puzzle together. In areas where there were gaps in the sequence, the students submitted requests for laboratory scientists at the Genome Institute to perform additional sequencing to cover these regions. "The students do a significantly better job at improving the sequence than the software does," says Elgin.

The team improved sequences from the dot chromosome and a euchromatic comparison region from three species of Drosophila that, together with D. melanogaster, are separated by 40 million years of evolution. To help them compare genes across the different genome sequences, the students used multiple types of evidence to predict the start, stop, and splice sites for each gene. These "punctuation marks" are critical to understanding how DNA is transcribed into RNA and translated into proteins. Start and stop sites tell the cellular machinery where to begin and end the translation of a sequence, and splice sites define where to chop out intervening sequences - introns - from the regions that code for proteins - known as exons.

Each chunk of sequence was examined by at least two independent groups of students, so they could cross-check findings and fix errors. The end result was a high quality data set that allowed the team, led by GEP staff member Wilson Leung, to statistically compare the properties of the dot chromosome to the euchromatic region in all four species.

This comparison revealed that most of the distinctive properties of the D. melanogaster dot chromosome are conserved across species. Dot chromosome genes have longer introns and more exons than the comparison region, as well as a higher density of repeat sequences. The accumulated repeats - mostly remnants of now inactive transposable elements - can partly explain why dot chromosome genes have larger introns (the introns contain more repeats), though it doesn't explain why the genes tend to have more coding exons.

Dot chromosome genes also showed fewer traces of the effects of natural selection. This agrees with theoretical predictions that natural selection should be less effective on heterochromatic genome regions. 


\section{Box 18.1: (continued)}

The analysis also uncovered a tantalizing clue to one of the ways dot chromosome genes could remain active despite being stuck in a heterochromatic state. The researchers found that dot chromosome genes contain fewer of the " $\mathrm{C}$ " and " $\mathrm{G}$ " bases (of the famous A, T, C, G components of DNA) than do genes in the euchromatic region. Because $\mathrm{Cs}$ and Gs bind together more tightly than As and Ts, the DNA strands that make up dot chromosome genes are likely easier to unwind, which might allow better access to the DNA for the proteins that turn genes on and off. Further research will be needed to test this idea.

The GEP students not only advanced science with their work, but they also learned about genetics and genomics in a hands-on way. This translated to greater educational benefits for the students.

"We think a lot of the benefit comes from asking students to weigh the evidence; sometimes it's contradictory, sometimes one clue is more reliable than another, sometimes the students need to dig a bit deeper," says Elgin. "Basically we're teaching them to look carefully at data and be suspicious, be skeptical."

The GEP has previously measured the program's educational performance and found that students learn more about genes and genomes compared to students who did not participate in a research-based genomics course. The GEP students also selfreport similar gains in their ability to analyze data and understand the research process as those who had spent a summer working in a research lab. Given enough time (on average, around $45 \mathrm{~h}$ of class time), GEP student gains even exceeded those of summer research students.

"Faculty are sometimes skeptical that this kind of project will work for their students. But the GEP includes a diverse range of schools serving different types of students and the learning gains were similar across every category we tested. I believe any student can benefit," says Elgin.

Read more at http://scienceblog.com/78332/tapping-the-potential-of-undergraduate-researchers/\#uEKWMOtzd4iMIDjC.99

Following the study reform related to the Bologna Process (i.e. the introduction of graduated and modularized degree programs), universities have, for the most part, definitively renounced the continuation of the project formats (Kruse 2009), especially as the increase in the number of students and their growing heterogeneity in skills, knowledge and interests have made it necessary to further develop the teaching concept. Instead, elements of inquiry-based learning were integrated into the curricula in less extensive formats or exclusively for selected students. With the additional funding by for example the federal 
Teaching Quality Pact, however, many institutions of higher education are rethinking this project tradition and are implementing similar or adapted formats in the natural sciences, for example

- project workshops and "tu projects," ZEWK Berlin (ZEWK 2015);

- Supervision of laboratory internships, TU Darmstadt (Homann 2011);

- Humboldt reloaded, University of Hohenheim (Universität Hohenheim 2015);

- interdisciplinary research competence, University of Bielefeld (Lenger et al. 2013).

\subsubsection{Understanding of Inquiry-Based Learning and Teaching Within the Context of the Natural Sciences}

In the natural sciences department at the Carl von Ossietzky University in Oldenburg, inquiry-based learning and teaching is understood to mean the interaction between students and researchers whereby scientific curiosity is increased, scientific work practiced and new knowledge generated. Students should thereby practice and intensify their competencies in areas that include a capacity for problem solving and analysis, reflection, collaboration in a team, internationality, project management, independence and responsible time-management.

In particular, the students should:

- develop, plan and implement their own research ideas,

- orient their research ideas towards the international standard for the field,

- establish personal and individual contacts with active researchers,

- be integrated into the research project of working groups and

- give their studies an international focus.

For this reason, instructors must

- include their own research into their teaching practice,

- acquire and apply (didactic) methods that promote students' independent scientific work,

- develop new forms of teaching and learning in communication with other instructors and

- get involved in student initiatives.

This catalog of requirements makes it clear that inquiry-based learning really cannot refer to an individual course or module, but must instead run like a common thread through the curriculum. 


\subsubsection{Properties of Academic Studies in the Natural Sciences in Relation to Inquiry-Based Learning Using the Example of the University of Oldenburg}

Academic studies in the natural sciences and in mathematics have some favorable characteristics that facilitate integrating elements of inquiry-based learning. (1) The natural sciences are not subjects with mass appeal, especially at the level of master's degree programs. Professional master's degree programs are tailored to the research interests of the research groups, since this is where the natural sciences recruit young academics. More than $3 / 4$ of new students in the school of mathematics and the natural sciences at the University of Oldenburg find an introduction to research to be important or very important (Albrecht 2015), which is significantly more than the average for all students in their first semester of university. (2) Furthermore, internships and tutorials are traditionally important components of a course of studies which extend through all phases of those study programs. Research methods are usually practiced in internships and tutorials, and sometimes students work on predetermined or autonomous projects. (3) The staff-to-student ratio is frequently good since, in addition to the instructor, additional student or scientific personnel are involved in classes. (4) Project work and thesis projects are often completed within the research groups, e.g. in the research laboratories. This establishes close contact with researchers and makes the standards required of scientific work tangible for students. (5) In chemistry and physics, for example, experiments that are also conducted in lectures demonstrate current research topics and methods. In addition, many degree programs have already established project or block formats years ago that allow a comprehensive and often interdisciplinary treatment of a topic with a great deal of flexibility in terms of time.

(6) The fact that there are many qualification positions for completing a doctorate or for postdoctoral qualification for teaching staff facilitates the research orientation in teaching. The young scientists bring a great deal of new impetus to teaching and enthusiasm for their field. (7) In addition, there is usually research-related and modern equipment available in the laboratories and workspaces since the research groups attract a great deal of third-party and special funding. (8) It is also important that scientific standards be applied in the international competition in the natural sciences; scientists compete for funding and publications within an international community. Both advanced study programs for postgraduates and research topics therefore have an international focus.

In addition to these aspects, which are favorable for inquiry-based learning, there are also unfavorable factors in the natural sciences. (1) Firstly, the study groups in many courses are very heterogeneous in terms of previous knowledge and motivation. (2) A secondary-school diploma (Abitur) or other university entrance qualification does not guarantee a minimum standard of knowledge in mathematics and the natural sciences. (3) In most disciplines, a great deal of prior knowledge is needed in order to develop a research question, the methods are often specialized, complex and expensive to implement. (4) Generally, interdisciplinary questions that are derived from everyday knowledge do not lead to testable hypotheses. (5) In many natural-science-related subjects, it is very important to systematically develop knowledge in a manner oriented toward the logic of the 
discipline (Fichten 2010). (6) In addition, the above-mentioned high turnover of nonprofessorial teaching staff in qualification positions has a negative impact, such that personnel are often inexperienced in instructing students and have little opportunity to systematically develop the teaching competence that is so critical for the format of inquirybased learning.

\subsection{Experiences with Inquiry-Based Learning in the Natural Sciences in a Project at the University of Oldenburg}

\subsubsection{Measures and Formats}

With all of this said, inquiry-based learning is more than a didactic trick, and instructors must conduct research themselves and be integrated into an environment in which scientific activity is actively being pursued. Convinced that there are many different ways and formats through which research and teaching can be linked (Healey 2005), various measures were supported at the University of Oldenburg and subsequently documented and evaluated. In addition to enriching the curriculum with additional personnel, teaching and learning formats that allow inquiry-based learning have been newly established and expanded. This includes the student labs that already exist for elementary school classes for the topics of the Wadden Sea, the human senses, the Green School, energy, automation technology and chemistry and that were expanded as research facilities for prospective teachers. Student labs are course formats in which school classes conduct experiments in facilities and using the equipment belonging to the university, and who are led by university students. In so doing, students can work on their own research questions concerning teaching-learning settings. The implementation of these measures was accompanied by higher education didactic courses for the lecturers, which were tailored to the change of perspective in inquiry-based learning.

\subsubsection{Modules/Courses Concerning Inquiry-Based Learning}

In many research areas, distinct formats have been developed so that inquiry-based learning can be especially well implemented. Here, most projects emphasized the ability of students to develop their own questions or to identify problems. A few examples of this from among the various thematic contexts have been outlined in Table 18.1:

\subsubsection{Summary Overview and Classification}

In order to integrate more elements of inquiry-based learning in the degree programs, a total of 17 different formats were developed and introduced. Most of the new courses have been developed for the professional master's degree programs, and many are also directed 
Table 18.1 Examples from the degree programs in the natural sciences at the University of Oldenburg in which the new inquiry-based learning formats have been integrated

\begin{tabular}{|c|c|c|c|}
\hline Format & Brief description & Degree program & Credits \\
\hline $\begin{array}{l}\text { Theoretic } \\
\text { (chemistry) }\end{array}$ & $\begin{array}{l}\text { Students will formulate and work on their own } \\
\text { questions, derive hypotheses and implement } \\
\text { these autonomously on the computer with } \\
\text { support from scientists. Participants will } \\
\text { program their own quantum chemical program } \\
\text { of any level of complexity and solve problems } \\
\text { as a team with guidance. }\end{array}$ & $\begin{array}{l}\text { Bachelor's } \\
\text { program in } \\
\text { chemistry }\end{array}$ & 6 \\
\hline $\begin{array}{l}\text { Student lab project } \\
\text { module in } \\
\text { automation } \\
\text { technology } \\
\text { (engineering) }\end{array}$ & $\begin{array}{l}\text { School students learn automation technology } \\
\text { based on the example of robots that are easy to } \\
\text { build and program. The increase in knowledge } \\
\text { among school students is recorded empirically } \\
\text { by the university students. Students gain insight } \\
\text { into didactic research and study the } \\
\text { effectiveness of their own teaching. }\end{array}$ & $\begin{array}{l}\text { Two-subject } \\
\text { bachelor's degree } \\
\text { in engineering }\end{array}$ & 6 \\
\hline $\begin{array}{l}\text { Proteomics } \\
\text { (marine science) }\end{array}$ & $\begin{array}{l}\text { Biological issues from current research topics } \\
\text { are processed and solved. To go deeper into the } \\
\text { topic, students give presentations on current } \\
\text { publications. Students evaluate the published } \\
\text { data statistically and categorize it. A tie-in to } \\
\text { the thesis work is possible. }\end{array}$ & $\begin{array}{l}\text { Master's degree } \\
\text { program in } \\
\text { microbiology }\end{array}$ & 12 \\
\hline $\begin{array}{l}\text { Meta-analyses of } \\
\text { marine } \\
\text { biodiversity } \\
\text { (marine science) }\end{array}$ & $\begin{array}{l}\text { Students develop their own initial hypotheses in } \\
\text { small groups. Suitable data records will be } \\
\text { handed out or students will search for data from } \\
\text { the published literature independently, then } \\
\text { evaluate the data and present the results. The } \\
\text { hypotheses they formulate themselves will } \\
\text { subsequently be investigated in laboratory } \\
\text { experiments. A tie-in to the thesis work is } \\
\text { possible. }\end{array}$ & $\begin{array}{l}\text { Master's degree } \\
\text { program in marine } \\
\text { environmental } \\
\text { sciences }\end{array}$ & 12 \\
\hline $\begin{array}{l}\text { Independent } \\
\text { research project } \\
\text { (biology) }\end{array}$ & $\begin{array}{l}\text { Students suggest projects that they could also } \\
\text { work on at a partner institution, for example } \\
\text { abroad. Support personnel is available to all } \\
\text { students for questions. The goal of the project } \\
\text { is to make independent scientific work possible. } \\
\text { A tie-in to the thesis work is possible. }\end{array}$ & $\begin{array}{l}\text { Master's degree } \\
\text { program in } \\
\text { biology }\end{array}$ & 15 \\
\hline $\begin{array}{l}\text { Teaching-learning } \\
\text { lab in laser optics } \\
\text { (physics) }\end{array}$ & $\begin{array}{l}\text { Students independently build the resonator on } \\
\text { the basis of calculations made in the group so } \\
\text { that the resonator can be used to operate the } \\
\text { laser. Due to the modular design, further } \\
\text { courses relating to such experiments can build } \\
\text { on this in coming semesters. }\end{array}$ & $\begin{array}{l}\text { Bachelor's } \\
\text { program in } \\
\text { physics }\end{array}$ & 6 \\
\hline
\end{tabular}


Table 18.1 (continued)

\begin{tabular}{l|l|l|l}
\hline Format & Brief description & Degree program & Credits \\
\hline $\begin{array}{l}\text { Correlation and } \\
\text { causality networks } \\
\text { in complex } \\
\text { systems (marine } \\
\text { science) }\end{array}$ & $\begin{array}{l}\text { The topic is the empirical reconstruction of } \\
\text { correlation and causality networks based on } \\
\text { multivariate data. The basics of theory and } \\
\text { application of mathematical methods are taught } \\
\text { in lecture units. Acquired methods can be } \\
\text { applied to data that is provided or students' } \\
\text { own datasets. In so doing, students develop and } \\
\text { process their own questions. }\end{array}$ & $\begin{array}{l}\text { Master's degree } \\
\text { program in marine } \\
\text { environmental } \\
\text { sciences }\end{array}$ & 6 \\
\hline $\begin{array}{l}\text { Student lab in the } \\
\text { Wadden Sea/ } \\
\text { teaching-learning } \\
\text { lab (biology) }\end{array}$ & $\begin{array}{l}\text { Students first develop learning arrangements on } \\
\text { the topic of the Wadden Sea. These are then } \\
\text { implemented together with the school students, } \\
\text { who work as independently as possible. }\end{array}$ & $\begin{array}{l}\text { Two-subject } \\
\text { bachelor's degree } \\
\text { in biology } \\
\text { the learning arrangements using didactic } \\
\text { research methods. }\end{array}$ & 6 \\
\hline
\end{tabular}

Source: author's representation

towards students in the bachelor's program. Another important element of independent research in the natural sciences is the preparation of a thesis, which is not listed separately here. Many of the courses containing elements of inquiry-based learning can be used as preparation for a thesis, however. The various formats include different tasks in the curricular acquisition of the competency to conduct independent research (on the basis of Deicke 2013):

Stage 1 - Receptive: Students acquire knowledge and abilities related to scientific research. Stage 2 - Applying or referring only to literature: Students make a narrowly defined contribution to a larger research project or review literature.

Stage 3 - Researching: Students work on their own research project.

In order to be able to systematically record the depth to which, and in what respects, the new formats included elements of inquiry-based learning in the degree programs, instructors were asked to classify their courses according to the categories of inquiry-based learning: in the receptive, applying and researching stages, and in the categories of research results, methods and processes, respectively (according to Deicke 2013). The explicit designation of methods and the application thereof make this model especially suited for the natural sciences. This often relates to research methods and to the implementation in practical action. The classification shows a focus in terms of the research methods, namely at all three levels of student activation (receptive, applying and researching); this is how nearly half of the projects carried out were classified. It is also striking that approximately 40 percent of the projects were assigned to the receptive stage, whereby a move towards 
more demanding levels of learning is desirable. At the same time, there are at least five formats that instructors described as allowing students to go through the entire research process autonomously, although the degree programs have not undergone any fundamental structural changes. This confirms that the curricula in mathematics and the natural sciences are well prepared for inquiry-based learning formats and that these formats have long been considered, for example when selecting the appropriate forms of examination.

\subsection{Conclusion and Outlook: Outlook for Inquiry-Based Learning in the Natural Sciences: What Needs to Be Done?}

Overall, both teaching staff and students benefited from the above-mentioned projects and formats, and the evaluations demonstrated that both sides were satisfied or even enthusiastic. Nevertheless, difficulties did arise. Students first had to understand and accept the new learning concept; many were unaccustomed to being able to pursue their own ideas. Once students had undergone this change in perspective, however, it was possible for them to continue to work very well. It was also difficult to deal with heterogeneous study groups with varying previous knowledge and different motivations for engaging in a change in perspective. This turned out to be particularly difficult in bachelor's courses. Some classes were perceived as being too specific. The size of the study group substantially impacts the success of the format: Neither those groups that were too small (fewer than 3 students), nor those that were too large (more than 20 students) were able to satisfactorily implement the planned concepts.

\subsubsection{What Are the Next Steps?}

With regard to the systematic and sustainable establishment of inquiry-based learning, the projects made it clear that the degree programs already have the necessary formal structures. Nevertheless, steps for further development are necessary:

Adjusting the Staff-to-Student Ratio Courses containing elements of inquiry-based learning require very intensive supervision and therefore would reduce the teaching capacity in other formats if established on a permanent basis. This would lead to the deterioration in the staff-to-student ratio in other courses. Therefore, a significant increase in the Curricular Standards $(\mathrm{CNW})$ - the planned teaching hours for a student's education - for degree programs with evident elements of inquiry-based learning is absolutely necessary.

Analysis and Further Development of the Research Orientation in the Degree Program Curricula A research orientation is an essential element of academic studies at the university. It is therefore appropriate to use this aspect to assess and, if necessary, adapt the degree programs in terms of continuous quality development. In so doing, the model developed by Wolfgang Deicke (Deicke, 2013) could be used. Each module can be 
arranged in this grid. That means that, in planning a degree program, an important aspect is the research orientation by applying inquiry-based learning. Based on this, the curriculum can be structured in terms of its systematic capacity building for independent research.

Integration into the Quality Development of Degree Programs The goal of sustainably establishing elements of inquiry-based learning can be achieved by systematically anchoring these in the curricula and the monitoring of success. The subject of elements of inquiry-based learning can be included as an operational goal in a quality-development system. As a result, inquiry-based learning will be anchored in such a way that it is reported on and the further development thereof documented. An indicator system would need to be worked out for this.

Impact Research Elements of inquiry-based learning in degree programs should be visible, further established and expanded so that students are better equipped to develop into autonomous, independent and responsible members of the global scientific community and society. In doing so, they should have acquired all of the competencies over the course of their studies that enable them to perform the corresponding functions as academics. Presumably, students who have experienced many elements of inquiry-based learning are therefore better able than other students to meet the educational goals of degree programs. Corresponding impact research must first demonstrate this, however.

\subsubsection{Outlook}

In the degree programs in the natural sciences, many practical and research-related elements already exist that make it easy to selectively integrate inquiry-based learning and self-determined action on the part of students. What is missing are formats adapted to the specific phase of a course of study (e.g. for motivation in the introductory phase of the course of study), a curricular build-up in research competence including interdisciplinary competencies, and systematic integration into a system in order to develop the quality of the degree programs, as well as comprehensive and fair concepts for sustainable establishment beyond the Teaching Quality Pact. What continues to be needed are concomitant impact research, in order to identify efficient models, and a reinforcement of the higher education didactic competence of the instructors through measures that are tailored to the scientific culture of natural sciences.

\section{References}

Albrecht, N. (2015). Studieneingangsbefragung 2014/2015. Retrieved 14 June 2015 from http:// www.uni-oldenburg.de/lehre/evaluation/interne-evaluation/studieneingangsbefragung/

Deicke, W. (2013). Implementing Research-Based Education: Challenges and Opportunities [Powerpoint-Folien]. Zugriff auf Vortrag an der Humboldt-Universität zu Berlin am 14.06.2015 von http://www.unica-network.eu/sites/default/files/20121205\%20UNICA\%20Bologna\%20 Lab\%20Deicke.ppt 
Fichten, W./Jaeckel, K./Stinshoff, R., (Hrsg.). (1978). Projektstudium und Praxisbezug. Reformmodelle der Lehrer- und Juristenausbildung. Frankfurt/Main, New York: Campus.

Fichten, W. (2010). Forschendes Lernen in der Lehrerbildung. In U. Eberhard (Hrsg.), Neue Impulse in der Hochschuldidaktik. Sprach- und Literaturwissenschaften (S. 127-182). Wiesbaden: VS Verlag für Sozialwissenschaften.

Genetics Society of America (2015). Tapping the potential of undergraduate researchers. More than 900 students co-author genomics research paper. Retrieved 03 March 2016 from http://www. genetics-gsa.org/media/releases/GSA_PR_201505_GEP.html

Healey, M. (2005). Linking research and teaching: exploring disciplinary spaces and the role of inquiry-based learning. In R. Barnett (Hrsg.), Reshaping the University: New Relationships between Research, Scholarship and Teaching (pp. 67-78). Maidenhead: McGraw Hill/Open University Press.

Homann, U. (2011). Qualifizierungskonzept und innovative Prüfungsform für die Betreuung von Laborpraktika in Studiengängen der Fächer Biologie und Chemie. Retrieved 14 June 2015 from http://www.stifterverband.info/ wissenschaft_und_hochschule/lehre/fellowships/fellows_2011/ homann/darmstadt_homann.pdf

Jung, E. (1997). Projekt - Projektunterricht: mehr als eine Methode. Schwalbach: Wochenschau-Verlag.

Kruse, E. (2009). Projektstudium und Praxisbezüge im Bologna-Prozess. Sozial Extra, 33, 1/2, 42-47.

Lenger, J./Weiss, P./Kohse-Höinghaus, K. (2013). Vermittlung interdisziplinärer Forschungskompetenz: Lehren und Lernen von- und miteinander. Zeitschrift für Hochschulentwicklung, 8, 60-68.

Universität Hohenheim (2015). Humboldt reloaded. Retrieved 14 June 2015 from https:// studium-3-0.uni-hohenheim.de/ueberblick

Wildt, J. (1981). Hochschuldidaktik und staatliche Studienreform. Zur Transformation des Projektstudiums im Spannungsfeld einer Studienreform von »oben « und »unten«. Materialien und Berichte, Bd. 13. Bielefeld: Interdisziplinäres Zentrum für Hochschuldidaktik der Universität Bielefeld.

Zentraleinrichtung Wissenschaftliche Weiterbildung und Kooperation (ZEWK) (2015). Projektwerkstätten und tu projects. Retrieved 14 June 2015 from http://www.projektwerkstaetten.tu-berlin.de/menue/ueber_projektwerkstaetten_und_tu_projects/

Open Access This chapter is licensed under the terms of the Creative Commons AttributionNonCommercial-NoDerivatives 4.0 International License (http://creativecommons.org/licenses/bync-nd/4.0/), which permits any noncommercial use, sharing, distribution and reproduction in any medium or format, as long as you give appropriate credit to the original author(s) and the source, provide a link to the Creative Commons licence and indicate if you modified the licensed material. You do not have permission under this license to share adapted material derived from this chapter or parts of it.

The images or other third party material in this chapter are included in the chapter's Creative Commons licence, unless indicated otherwise in a credit line to the material. If material is not included in the chapter's Creative Commons licence and your intended use is not permitted by statutory regulation or exceeds the permitted use, you will need to obtain permission directly from the copyright holder. 